\title{
Antiformalismo Jurídico: uma Abordagem Institucionalista da Integração Regional
}

\author{
Clarissa Franzoi Dri*
}

Resumo: No início do século XX, na contracorrente da supremacia estatal e defendendo a harmonização dos ordenamentos e a predominância do direito internacional, surgem doutrinas monistas diferenciadas para explicar as relações entre os ordenamentos interno e internacional. Concebendo o Estado como somente uma das muitas formas de organização social, essas escolas prescindem de sua figura para explicar o direito internacional. $\mathrm{O}$ artigo analisa o antiformalismo institucionalista da escola italiana, e seus efeitos na interpretação da integração regional, analisando obras de Maurice Hauriou, Santi Romano e Riccardo Monaco.

Palavras-chave: Direito Internacional, Integração Regional, Antiformalismo, Institucionalismo Jurídico, Soberania.

Abstract: In the beginning of the $20^{\text {th }}$ century, new monist doctrines rise up to explain the relations between national and international law. These theories question the state supremacy and defend the prevailing of the international law. In this view, the state becomes only one of the various forms of social organization and it is not a requisite to explaining the international law. This paper analyses the institutional antiformalism of the Italian school, and its effects on the interpretation of the regional integration, analysing works of Maurice Hauriou, Santi Romano and Riccardo Monaco.

Keywords: International Law, Regional Integration, Antiformalism, Juridical Institutionalism, Sovereignty.

\footnotetext{
* Doutoranda do Instituto de Estudos Políticos de Bordeaux (Universidade Montesquieu - Bordeaux IV), Mestre em Direito - Relações Internacionais da Universidade Federal de Santa Catarina e Bacharel em Direito da Universidade Federal de Santa Maria - RS. E-mail: clarissadri@yahoo.com.br. Recebido em 12/05/08 e aceito em 09/06/08.
} 


\section{O direito internacional entre positivismo e antiformalismo}

O Estado moderno consolidou-se como resposta a uma necessidade da burguesia européia. Era indispensável à legitimação do incipiente sistema de produção capitalista que o novo regime sócio-político fosse formalmente democrático, o que requeria instrumentos de limitação do poder monárquico e de representação da vontade geral ${ }^{1}$. Entre outros "mitos da modernidade" 2 , as assembléias parlamentares e o princípio da legalidade constituíram-se em fundamentos da democracia nascente. Assentado sobre um discurso abstrato e dogmático, esse modelo perpetua-se há séculos como a principal forma considerada possível de organização da vida em sociedade. Partindo dessas consideraçóes, o artigo procura questionar a adoção do modelo estatal e discutir seus efeitos nas relações jurídicas internacionais. Por meio de uma revisão de literatura, busca-se apresentar as teorias precursoras da escola chamada "antiformalista" e sua perspectiva do direito internacional contemporâneo e da integração regional.

Embora tudo pareça encaixar-se perfeitamente na construção do Estado, como em um teorema (GROSSI, 2004, p. 61) ${ }^{3}$,

por trás deste palco cênico em que tudo é idealizado, por trás deste raciocínio realizado através de modelos, fica escondido o Estado monoclassista, o espesso extrato de filtros entre sociedade e poder, o elitismo exclusivo das formas de representação, a grosseira defesa de ricos interesses que todo o puríssimo teorema vinha a tutelar e a consolidar. [...] aparece ideologicamente carregada a verdade axiomática de que a lei, e somente a lei, exprime a vontade geral e, assim sendo, produz e condiciona toda a manifestação da juridicidade; ou seja, tudo o que venha proposto como juridicidade mostra-se, em um exame aprofundado, mais

\footnotetext{
${ }^{1}$ Segundo a noção elaborada pelo filósofo francês Jean-Jacques Rousseau, "há comumente grande diferença entre a vontade de todos e a vontade geral; esta só fita o interesse comum; aquela só vê o interesse, e não é mais do que uma soma de vontades particulares; porém quando tira dessas vontades as mais e as menos, que mutuamente se destroem, resta por soma das diferenças a vontade geral” (2001, p. 41).

${ }^{2}$ Veja Grossi (2004) e Wolkmer (2001, p. 25-78).

${ }^{3}$ Explica-se 0 autor: "A engenhosidade e o esmero da paisagem também se revelaram na sua harmonia de construção geométrica, onde tudo aparece exato e preciso, contido, como é, no rigor de linhas, ângulos, círculos. O problema ineliminável e indissolúvel é o fato de não se discorrer sobre figuras abstratas, mas sobre criações e criaturas históricas inconteníveis no rigor de um teorema. E trata-se de um verdadeiro teorema político-jurídico" (2004, p. 61, grifo nosso).
} 
como uma pseudo-verdade substancialmente tuteladora de interesses particulares dos detentores do poder (GROSSI, 2004, p. 62).

Nessa lógica, são questionáveis as idéias de que a legislação transparece a vontade do povo e de que nela residem as garantias indispensáveis contra abusos do poder. Ao contrário, foi exatamente por meio desses argumentos, racional e ideologicamente construídos, que se propagou a noção, hoje dominante nos ordenamentos da família romano-germânica, de que o direito é idêntico à lei ${ }^{4}$. Essa identificação traduz as diretrizes do positivismo jurídico, que se caracteriza pela redução do direito à ordem estabelecida, através das normas emanadas do Estado.

Além da crítica aos motivos pelos quais o positivismo norteia a vida jurídica do Estado desde a modernidade, é imprescindível apontar as falhas de sua aplicação 5 . Em primeiro lugar, ele não admite a presença de lacunas, que, a despeito de tal preceito, podem existir no sistema jurídico. $\mathrm{O}$ positivismo também encontra dificuldade para lidar com as proposiçóes normativas abertas (como as normas penais em branco), entregando-as a um de seus maiores inimigos: a interpretação do juiz (discricionária ou, por vezes, arbitrária). Depois, ele é inoperante em face do conflito entre princípios, que não são admitidos como normas pelos positivistas, mas estão presentes no ordenamento. O sistema positivista de matriz kelseniana, assim, apresenta limitaçóes incontornáveis, tanto formais quanto materiais, para explicar a vinculação entre os homens e o ordenamento que regula sua vida em meio à coletividade. Isso porque o direito deve exprimir a sociedade, não o Estado, nascendo, portanto, antes da norma (GROSSI, 2006, p. 11). Ela é puramente declaratória, não constitutiva da juridicidade que já se verifica no desenrolar das relaçóes entre as pessoas. Nessa ótica, a centralidade do direito deixa de estar no aparato normativo estatal e passa ao ser humano.

As restriçóes positivistas parecem se repetir na cena internacional ${ }^{6}$. Se o

\footnotetext{
4 "A identificação entre Direito e lei pertence, aliás, ao repertório ideológico do Estado, pois na sua posição privilegiada ele desejaria convencer-nos de que cessaram as contradições, que o poder atende ao povo em geral e tudo o que vem dali é imaculadamente jurídico, não havendo Direito a procurar além ou acima das leis” (LYRA FILHO, 2003, p. 8).

${ }^{5}$ Estes e outros aspectos que desnudam a fragilidade do positivismo, no tocante a seus efeitos, são trazidos por Grau (1996, p. 26).

6 "O Direito não se limita ao aspecto interno do processo histórico. Ele tem raiz internacional. [...] o direito entre nações luta para não ficar preso ao sistema de forças dominantes e, em que pesem as felizes contradições, a sua forma interestatal (entre Estados) reproduz, no ângulo externo, a obstrução [...] quanto ao direito estatal” (LYRA FILHO, 2003, p. 72-73).
} 
principal efeito do positivismo nos ordenamentos nacionais é a supremacia das fontes estatais, no direito internacional ele fomenta a noção de que o Estado, soberano, é seu único sujeito pleno. Desse modo, o Estado, organização social superior, protagoniza a cena jurídica, seja ela interna ou externa às suas fronteiras. Para legitimar esse monopólio, são necessárias teorias que expliquem as relaçôes entre direito interno e direito externo. Assim surgem as doutrinas dualistas e monistas.

O dualismo deriva diretamente das teorias voluntaristas do direito internacional. Elas afirmam que o direito encontraria sua origem na expressão da vontade estatal. O Estado possuiria autonomia para submeter-se ou não às normas internacionais, de acordo com seus interesses. Um requisito indispensável para a vinculação ao direito seria o consentimento estatal. Se no voluntarismo unilateral o direito internacional nasce das vontades isoladas dos Estados, o voluntarismo multilateral considera que ele resulta da vontade comum dos Estados ${ }^{7}$. Ambas correntes de pensamento levam a uma dissociação inevitável entre os ordenamentos jurídicos interno e externo. Uma vez que o ordenamento internacional consistiria em um conjunto de normas paralelo ou alheio ao direito interno, o Estado poderia medir a pertinência de sua subordinação a ele ${ }^{8}$.

O voluntarismo positivista, ou neovoluntarismo, por sua vez, admite que o direito não é criado artificialmente pelo Estado, mas advém da vida em sociedade ${ }^{9}$. Não seria possível, assim, conceber um voluntarismo absoluto, tendo em vista que o direito deriva da realidade social. Entretanto, se o direito prescinde do Estado do ponto de vista material, formalmente tal intervenção é necessária. Seria preciso que o Estado "carimbasse" as normas sociais, transformando-as em normas jurídicas. Apesar da relativização da vontade estatal, seu reconhecimento persiste como necessário ao direito

${ }^{7}$ Georg Jellinek e Karl Heinrich Triepel são, respectivamente, os principais expoentes das referidas teorias.

${ }^{8}$ Para Karl Heinrich Triepel, não somente as vontades formadoras diversas, mas também as diferentes relações sociais que reguladas fazem do direito internacional e do direito interno noções destoantes e opostas. "Se as deduções que acabam de ser feitas forem exatas, delas resulta esta conclusão: o direito internacional público e o direito interno são, não somente partes, ramos, distintos do direito, como também sistemas jurídicos diferentes. São dois círculos em íntimo contato mas que jamais se superpõem. [...] Nossa tese significa, de resto, que jamais a formação do direito internacional público pode substituir a formação do direito interno; a fonte do direito interno deve agir por si mesma para tornar, de qualquer modo, seu, o direito criado pela fonte de direito internacional. [...] A doutrina que acaba de ser exposta pode ser denominada: 'teoria dualista das relações entre o direito internacional e o direito interno"” (1966, p. 15-18).

${ }^{9}$ Dionísio Anzilotti e Arrigo Cavaglieri são os principais expoentes dessa teoria. 
internacional, mantendo-se, assim, o dualismo.

Essa escola evidencia as influências positivistas e formalistas no direito internacional. Sob a ótica de que a norma jurídica é aquela posta pelo Estado, consolida-se o ofuscamento das relaçóes sociais como produtoras do direito. Quando se admite que a norma emana da sociedade, mas requer-se uma autoridade constituída para dar-lhe validade, coloca-se o elemento formal sobre o substancial. Tal sobreposição dos aspectos formais sobre os materiais consiste justamente no formalismo jurídico. Essa concepção define o direito exclusivamente em função de seus contornos, de seu esqueleto formal, prescindindo completamente do seu conteúdo - “isto é, considera somente como o direito se produz e não o que ele estabelece" (BOBBIO, 1995, p. 145). As relações entre as concepçóes positivista e formalista do direito não são de similitude nem de contrariedade. Trata-se de doutrinas diferentes que se complementam no tocante à manutenção do vazio ideológico atribuído ao direito.

Em objeção às teorias voluntaristas, desenvolve-se a doutrina normativista ${ }^{10}$, baseada na "teoria pura do direito" kelseniana. Segundo essa corrente, o fundamento do direito internacional está na normatividade que lhe é conferida por uma regra jurídica anterior e superior. No topo da pirâmide de Kelsen encontra-se a norma fundamental, fonte suprema do direito, em substituiçáo à vontade estatal. $\mathrm{O}$ direito interno e o direito internacional, alicerçados sobre a mesma base, formariam parte de um único ordenamento, o que configura o monismo internacional ${ }^{11}$. Essa fundamentação, contudo, parece insuficiente face à impossibilidade de justificar o fundamento da norma suprema. Apesar de diferenciar-se das teorias anteriores no tocante à aproximação entre os direitos externo e interno, a escola perde em realismo ao depositar o fundamento das normas em outra norma, igualmente abstrata e hipotética.

No início do século XX, na contra-corrente da supremacia estatal e defendendo a harmonizaçáo dos ordenamentos e a predominância do direito internacional, surgem as doutrinas monistas italiana e francesa. Concebendo o Estado como somente uma das muitas formas de organização social, as

\footnotetext{
${ }^{10}$ Gerada na Escola de Viena e representada, principalmente, por Hans Kelsen e Alfred Verdross.

${ }^{11}$ Veja Kelsen (1976, p. 300-303) e Kelsen e Campagnolo (2002).
} 
escolas prescindem de sua figura para explicar o direito internacional. Para a última corrente, mais centrada no indivíduo, o direito fundamentase nas relaçóes entre as pessoas e entre as sociedades, o que configura o monismo intersocial. No caso da teoria italiana, não é o indivíduo, mas são os agrupamentos humanos, as instituiçôes sociais que, ao interagirem, identificam-se ao direito, o que origina o monismo interinstitucional.

A consideração dos monismos intersocial e interinstitucional na tentativa de compreensão do direito internacional contemporâneo representa uma significativa mudança de paradigmas. Ousa-se questionar o dogma estatal de origem moderna. Aceitam-se como obsoletas certas construçóes racionais iluministas que encorajaram o domínio do direito positivo sobre os homens. Buscam-se fundamentos temporal e substancialmente mais próximos da realidade atual para explicá-la. É reconhecida uma pluralidade de atores internacionais, vinculados ou não ao Estado, que procuram ser vistos e ouvidos para além das fronteiras territoriais. Nessa lógica, os processos de integração surgem como requintados laboratórios do fim do absolutismo estatal e da aplicaçáo das doutrinas antiformalistas.

A seguir, nos itens 3 e 4, será abordado o modo pelo qual Santi Romano, no âmbito da escola italiana, delineia o monismo em sua obra ${ }^{12}$, como forma de compreender os fundamentos que são atribuídos, pelo antiformalismo institucionalista, ao próprio direito internacional público. Antes disso, o item 2 procurará explicar os pressupostos do conceito de instituição utilizado por Romano, cujo precursor é o francês Maurice Hauriou. Por fim, o item 5 traz uma análise da interpretação antiformalista de Riccardo Monaco acerca do ordenamento jurídico sui generis que nasceu com o processo de integração europeu.

\section{Maurice Hauriou e a doutrina institucionalista}

O institucionalismo surge a partir da segunda metade do século XIX,

\footnotetext{
${ }^{12}$ Embora aqui se refira ao monismo da teoria romaniana, existem interpretações segundo as quais Santi Romano teria se posicionado pelo dualismo entre direito internacional e direito interno (Riccardo Monaco e Roberto Ago). Para outros autores, Romano pertenceria a uma doutrina situada próxima ao pluralismo internacionalista (Piero Ziccardi e Alain Pellet).
} 
como reação ao individualismo e ao relativismo formalista que se afirmavam na cultura jurídica européia ${ }^{13}$. A doutrina foi influenciada pelos novos métodos aplicados nas ciências exatas - o empirismo e o experimentalismo -, bem como pelo florescimento dos movimentos socialistas que questionavam a lógica econômica liberal dominante. Os institucionalistas buscavam uma teoria que vinculasse o direito às suas bases sociais e que derivasse do exame da realidade, já que a vida começava a deixar de caber no discurso que os juristas costumavam fazer dela (HESPANHA, 2005, p. 403). O conceito de instituição nasce buscando superar a idéia de sociedade como uma justaposição de indivíduos autônomos e, para isso, destaca o papel da coletividade na construção do direito.

Trata-se de um transpersonalismo, isto é, de uma doutrina que radica o direito não nas pessoas individualmente consideradas, mas em realidades englobantes (os grupos humanos ou certas idéias normativas próprias e necessárias). São estas realidades ("instituiçóes”, por exemplo a família, a propriedade, o Estado) que, dispondo de uma normatividade em si, atribuem a cada um o "suum" (seu). O direito de cada um é, portanto, derivado e não próprio ou subjetivo (ou seja, radicado no sujeito) (HESPANHA, 2005, p. 309, grifos no original).

A vertente institucionalista que influenciou diretamente os estudos de Romano é aquela formulada por Maurice Hauriou ${ }^{14}$. O jurista francês fez parte do movimento de crítica ao positivismo jurídico, doutrina que vinha se consolidando fortemente na Europa continental. Na esteira do pensamento de León Duguit ${ }^{15}$, opunha-se à postura ultralegalista da escola exegética francesa, que configurou a base teórica da codificação civilista de Napoleão

\footnotetext{
${ }^{13} \mathrm{~A}$ escola histórica alemã, por meio de um dos seus ramos - a pandectística ou jurisprudência dos conceitos - ocupou um papel decisivo na difusão dessas noções. Veja Hespanha (2005, p. 391-400).

${ }^{14}$ Maurice Hauriou (1856-1929), jurista francês, doutorou-se em Bordeaux em 1879 e foi professor da Faculdade de Direito de Toulouse entre 1906 e 1926. Entre suas principais obras, estão Précis de Droit Administratif (1892), La Science Sociale Traditionelle (1896), Principes de Droit Public (1910), Précis de Droit Constitutionnel (1929) e L'ordre social, la Justice et le Droit (1927).

${ }^{15}$ León Duguit (1859-1928), jurista francês, foi professor de direito em Caen e Bordeaux. Entre suas principais obras, podem-se citar L'Etat, le Droit Objectif et la Loi Positive (1901), L'État, les Gouvernants et les Agents (1903), Souveraineté et Liberté (1920), Les Transformations du Droit Public (1928) e Traité de Droit Constitutionnel (1911).
} 
(WOLKMER, 2006, p. 192). Hauriou questionava a identificação do direito com a lei e propunha uma reconsideração das fontes jurídicas não-estatais.

Para o autor, a ciência jurídica deve buscar o equilíbrio entre sua forma e seu conteúdo. Esse equilíbrio, no entanto, não deve se estabelecer, como imaginam os positivistas, por meio da prevalência final da forma, mas sim do conteúdo - que é identificado à liberdade humana condicionada pela ordem social e pela justiça. Isso porque o formalismo, geralmente presente no início dos períodos históricos do direito, cede lugar, paulatinamente, às interpretaçóes materiais. Esse movimento verifica-se sobretudo no tocante a questôes sobre ilegalidade e inconstitucionalidade, oportunidade em que as determinaçóes jurisprudenciais necessitam recorrer à matéria suscitada, não apenas à letra da lei ${ }^{16}$.

Segundo Hauriou, o normativismo da lei escrita é infinitamente mais perigoso que os métodos costumeiros empregados pelo juiz. Entre as razóes de sua afirmação, ele aponta: (a) a lei, por sua própria natureza escrita e por sua tentativa de previsão de um futuro incerto, enseja reformas inevitáveis. $\mathrm{O}$ costume, ao contrário, vem do passado, mas pode ser coadunado pelo juiz às necessidades do presente; (b) a lei depende de uma certa atmosfera política, e é por ela determinada, diferentemente do costume, diretamente vinculado à sociedade; (c) a lei apresenta um caráter de generalidade bem mais imediato do que o costume, e, por esse motivo, desperta nos espíritos necessidades e desejos latentes ${ }^{17}$.

Baseado nesses pressupostos e na observação da multiplicidade de agrupamentos associativos surgidos ao final do século $\mathrm{XIX}^{18}$, o jurista

16 "Observando imparcialmente a evolução do Direito, vê-se que, em um período determinado, sem sacrificar em absoluto um dos elementos, ele vai da forma ao fundo" (HAURIOU, 1929, p. VI). Livre tradução do original: "A observer sans parti pris l'évolution du Droit, on voit que, dans une période donnée, sans jamais sacrifier l'un des éléments à l'autre, il va de la forme au fond." Criticando o positivismo jurídico, Hauriou afirma: "O dualismo entre forma e matéria, irredutível há quatro mil anos de filosofia, é um desses limites para todos que possuem uma preocupação com o real. Mas o orgulho da ciência prefere disfarçar a quimera. $\mathrm{O}$ monismo enérgico e formal foi obstinadamente perseguido nas ciências há um século sem jamais ser atingido" (1929, p. XII). Livre tradução do original: "Le dualisme de la forme et de la matière, irréductible depuis quatre mille ans de philosophie, est une de ces limites pour tous ceux qui ont la préoccupation du réel. Mais l'orgueil de la science préfere chevaucher la chimère. Le monisme énérgétique et formel a été obstinément poursuivi dans les sciences depuis un siècle sans jamais pouvoir être atteint."

${ }^{17}$ Hauriou (1929, p. 234)

18 "Se a supressão do corporativismo que existia sob o Antigo Regime foi a 'grande obra' da Revolução de 1789, instaurando um regime que atingia com sanções a formação de qualquer associação com mais de vinte pessoas sem autorização do 
desenvolve uma teoria institucionalista do direito. Se é por meio dos grupos organizados que os indivíduos logram uma melhor defesa de seus direitos, constata-se o fim da unicidade da ordem jurídica: o direito compóe-se de várias organizaçóes, englobando ou mesmo contrariando o Estado. Esses agrupamentos somente tornam-se duráveis, conservando sua forma específica a despeito das contínuas renovaçóes em sua matéria humana, quando são instituidos, isto é, quando sua idéia diretriz e sua forma equilibram-se em um consenso entre seus membros, o poder que os conduz e o meio social (HAURIOU, 1929, p. 73). As instituições representariam, assim, tanto no direito como na história, a categoria da duração, da continuidade e do real. Elas se realizariam e durariam juridicamente fundadas em dois fatores: em um poder que as organiza e em um grupo social que produz as manifestaçóes de vontade comum, dirigidas pelos órgãos do poder e reguladas pelos procedimentos (HAURIOU, 1933, p. 97).

Mas como fundar a autoridade dessa associação sobre seus membros e, ao mesmo tempo, definir os limites de sua autoridade? Ou como fundar a autoridade do Estado sobre esses agrupamentos, evitando simultaneamente a submissão destes àquele? Essas questóes levam Hauriou a tratar da regulação social das instituiçóes, sem cogitar o desaparecimento ou o enfraquecimento da ordem estatal. As instituiçóes seriam fontes jurídicas às quais deve se adequar o direito do Estado. Náo haveria, assim, uma pluralidade de ordenamentos, mas uma pluralidade de fontes, mantendo-se a supremacia estatal. "O Estado não é uma das instituiçóes que compõem a sociedade, mas a instituição das instituiçóes, aquela que engloba todas as outras e tenta realizar a ordem e a justiça" (BILLIER, MARYIOLI, 2005, p. 312, grifos no original). Percebe-se que o objetivismo da teoria é limitado pela afirmação permanente da autoridade estatal. A realidade objetiva que constitui uma associação sobrepóe-se, segundo o jurista, ao ato subjetivo - ou seja, o instrumento legal - que a cria, mas submete-se ao controle do Estado. A instituição configuraria, assim, um espaço de conciliação entre antinomias em princípio inconciliáveis, como o direito positivo do Estado e o direito da sociedade (BILLIER, MARYIOLI, 2005, p. 330).

Estado, a pressão dos fatos levou o Estado a votar a lei sobre os sindicatos (1884), sobre as sociedades de socorro mútuo (1898) e, por fim, a consagrar pela lei de 1901 a liberdade de associação que só teve valor constitucional na França a partir de 1971." (BILLIER, MARYIOLI, 2005, p. 308, grifo no original). 


\section{Santi Romano: o direito como ordenamento}

Se, por um lado, a teoria institucionalista de Santi Romano ${ }^{19}$ encontrou embasamento teórico nas idéias de Hauriou, por outro acabou por se afastar delas em termos específicos ${ }^{20}$. Uma das principais incongruências reside no fato de que Romano não considera que a instituição seja fonte do direito e que o direito seja então um produto dela, mas imagina, ao contrário, que entre o conceito de instituição e o de direito, ou melhor, de ordenamento jurídico integralmente considerado, exista uma perfeita unidade (DAL RI JR, 2006, p. 6) ${ }^{21}$.

Romano somente poderia chegar a esse resultado buscando superar a doutrina tradicional que reduz o conceito de direito à norma ou a um complexo de normas. Essa concepção seria inadequada e insuficiente ${ }^{22}$. Ele admite que, por vezes, o aspecto normativo sobressai-se, mas insiste que a

\footnotetext{
${ }^{19}$ SantiRomano(1875-1947),juristaitalianonascidonaSićlia,foiprofessordasuniversidadesdeCamerino,Modena,Pisa,Milão e Roma. Foi presidente do Conselho de Estado (1928), diretor da seção Direito Público da Enciclopédia Italiana (1925-1937) e sócio da Accademia Nazionale dei Lincei (1935-1946). Entre suas principais obras, estão L’Ordinamento Giuridico (1918), Principi di Diritto Amministrativo Italiano (1901), Corso di Diritto Coloniale(1918), Corso di Diritto Internazionale (1926), Principi di Diritto Costituzionale Generale (1945), Frammenti di un Dizionario Giuridico (1947) e Scritti Minori (1950).

20 "O institucionalismo de Hauriou e o de Romano de modo algum podem identificar-se: nem em suas teses originárias, nem no desenvolvimento das mesmas" (BAQUER, 1963, p. 47). Livre tradução do original: "El institucionalismo de Hauriou y el de Romano en modo alguno pueden identificarse: ni en sus tesis originarias ni en el desarollo de las mismas." Para Stefania Paliani, é na noção de necessidade que reside uma das principais diferenças entre os autores: "O pensamento científico de Santi Romano se concretiza na teoria da instituição, que, considerada no seu momento genético, apresenta-se como teoria da necessidade e, no seu momento, essencial resulta ser teoria da instituição como vida e vitalidade. A teoria da necessidade é o fundamento do institucionalismo romaniano. A necessidade é o pressuposto da teoria de Romano e constitui o elemento diferencial entre a instituição romaniana e aquela de Hauriou. Para Romano, o direito não é um produto social, porque é na necessidade que encontra o fundamento, sendo a mesma necessidade direito. Na instituição de Hauriou a necessidade não encontra espaço, já que, para o institucionalista francês, o direito nasce da organização de um poder em torno a uma idéia" (2007, p. 2). Vitório Emmanuele Orlando, por sua vez, argumenta que os trabalhos de Hauriou e Romano seguiram caminhos autônomos, sem influências recíprocas, tendo o jurista francês elaborado uma teoria mais sociológica do que propriamente jurídica (PALIANI, 2007, p. 7).

21 "O conceito que nos parece necessário e suficiente para trazer em termos exatos o conceito de direito, como ordenamento jurídico considerado no seu todo e unitariamente, é o conceito de instituição. Todo ordenamento jurídico é uma instituição e, vice-versa, toda instituição é um ordenamento jurídico. A equação entre os dois conceitos é necessária e absoluta" (ROMANO, 2006, p. 26).

22 "Não se trata de reduzir o valor do normativo, mas simplesmente de proclamar que essa ordem não esgota em si mesma a realidade jurídica" (BAQUER, 1963, p. 36). Isso significa afirmar que as normas devem estar em perfeita conexão e dependência com a totalidade do ordenamento jurídico, com sua aplicação, interpretação e integração.
} 
teoria jurídica deve considerar outros elementos que, além da norma, seriam essenciais e característicos ao direito - por exemplo, a sociedade (direito como manifestação social), a ordem social (direito como regulação) e a organização social (direito como fator estruturante e organizativo das relaçóes sociais e políticas) (ROMANO, 2006, p. 25-26) ${ }^{23}$. A totalidade e a complexidade desses fatores seriam contempladas na compreensão do direito enquanto instituiçâa $0^{24}$.

Mas não se trata, aqui, de instituição no sentido de pessoa jurídica, como já havia esclarecido Hauriou. Trata-se, isso sim, de um conjunto de meios materiais e pessoais, que conformam um corpo social dotado de autonomia. A instituição, assim, é uma verdadeira realidade social dotada de individualidade própria e objetiva, embora se relacione com outras entidades. É manifestação da natureza social do homem e tem existência permanente, mantendo-se mesmo com a contínua renovação de seus membros. Romano estabelece, no entanto, uma gradação: o Estado e a comunidade internacional seriam instituiçóes complexas (ou instituiçóes de instituiçóes), enquanto que as entidades públicas subordinadas ao Estado e seus órgãos seriam instituiçóes simples (ROMANO, 2006, p. 34).

Para justificar a necessidade da consideração de elementos externos à norma na definição de direito, Romano apresenta três argumentos principais. Em primeiro lugar, o jurista afirma que o direito, como ordenamento, nasce antes de seus aspectos normativos e freqüentemente alcança momentos que não podem ser confundidos com aqueles que caracterizam normas. Isso porque sua concepção de direito é unitária: o ordenamento jurídico não é

\footnotetext{
${ }^{23}$ Romano (2006, p. 25-26). Alguns ramos do direito, como o privado e o penal, dão mais destaque à norma. Em outros, a teoria do direito como instituição é mais facilmente verificável. Nos campos constitucional e administrativo, por exemplo, negar o viés institucional e reduzir o fenômeno jurídico à norma significaria anular quase todo o direito. Isso porque essas áreas não se limitam a disciplinar relações individuais e concretas no seio do Estado, mas contemplam o Estado em si, sua estrutura e funções (ROMANO, 2006, p. 77).

24 "A instituição é um ordenamento jurídico, uma esfera em si mesma, mais ou menos completa, de direito objetivo. [...] Não temos dúvida de que ela seja um ordenamento: as palavras organização, sistema, estrutura, edifício etc, com as quais é qualificada, tendem a evidenciar este conceito. [...] Isso significa que a instituição no sentido por nós delineado é a primeira, originária e essencial manifestação do direito. Este pode se manifestar somente em uma instituição, e a instituição, no entanto, existe e pode ser dita tal enquanto é criada e mantida em vida pelo direito" (ROMANO, 2006, p. 37-38). "Mesmo se, em um certo sentido, poderia ser exato concebê-la [a instituição] como o corpo, a ossatura, o tecido do direito, isso não faz com que este último possa vir a ser separado dela, nem materialmente nem conceitualmente, assim como não se pode distinguir a vida do corpo vivo" (ROMANO, 2006, p. 40).
} 
a soma de várias partes, mas uma unidade em si, concreta e diferente dos elementos materiais que o compóem. Logo, não é possível ter uma noção adequada das normas que nele estão compreendidas sem antes ter a noção do todo. "Do mesmo modo, não é possível ter uma idéia exata dos vários membros do homem ou das rodas de uma determinada máquina se não se sabe antes o que é o homem ou o que é aquela máquina” (ROMANO, 2006, p. 15).

Em segundo lugar, a sanção e o Estado surgem antes das normas. Embora ambos elementos sejam freqüentemente considerados extrajurídicos, fazem parte do mundo do direito. No caso das sançóes, antes de serem fatores acessórios ou secundários às normas, são fatores que as condicionam e antecedem, na medida em que a obrigatoriedade do direito consiste no terreno sobre o qual se assenta o sistema normativo. Já o Estado, para Romano, confunde-se com o ordenamento jurídico estatal. Esse não é somente o conjunto de regras e preceitos emanados pelo Estado, mas é a própria expressão do fenômeno estatal (ROMANO, 2006, p. 64) ${ }^{25}$. Logo, o Estado não está fora nem vem antes do direito, mas nasce com este ${ }^{26}$.

Em terceiro lugar, afirmar que o direito equivale à norma significa definilo por seus aspectos formais (ROMANO, 2006, p. 18). Santi Romano não vê razão para conceituar ao direito mais pela sua roupagem do que pela substância das normas que o comporiam.

A noção de ordenamento traduz a busca de Romano pelos fundamentos materiais do direito. Ela contrapóe-se à idéia de direito enquanto poder, na medida em que reflete "um direito que nasce de baixo, sob a égide de uma clara espontaneidade", que se refere a uma dimensão ôntica da sociedade,

\footnotetext{
25 "Mesmo sendo verdade que o Estado se auto-limita quando põe o seu ordenamento jurídico, não existe algum momento em que este não seja limitado, justamente porque, desde a sua origem, ele é um ordenamento: a sua auto-limitação pode ser somente uma limitação ulterior. Deste modo, a lei nunca é, como freqüentemente se acredita, o começo do direito: é, ao contrário, uma complementação ao direito precedente (na hipótese que este tenha lacunas) ou uma modificação do mesmo. Desta forma, o legislador não é o criador do direito no sentido pleno e absoluto do termo, o seu primeiro criador; daí advém a falta, nele, de um poder para anulá-lo completamente. Para anular o direito, deveria decretar o fim do Estado" (ROMANO, 2006, p. 65).

${ }^{26}$ Segundo Romano, o direito refere-se sempre a uma determinada coletividade. A formação de uma sociedade e de seu direito acontecem ao mesmo tempo e na mesma velocidade. É evidente, assim, que o direito somente pode ser estudado com relação ao seu substrato social, do qual é parte necessária e organizativa. $\mathrm{O}$ assento social é ele mesmo uma organização jurídica, ou seja, constituição. Essa não se restringe, então, à disciplina das normas jurídicas (ZICCARDI, [198?], p. 318).
} 
porque é radicado nela e ativo na consciência coletiva e a uma dimensão objetiva, já que é primeiro auto-organização e, depois, norma (GROSSI, 2007 , p. 3$)^{27}$. Nesse sentido, aproxima-se mais do direito costumeiro da Idade Média do que do sistema de normas surgido com a modernidade, quando o direito se subjetiva, dependendo da vontade do soberano, e transforma-se em instrumento de controle social. O risco - concretizado entre os séculos XIX e XX - da separação entre a regra autoritária imobilizada em um texto e a vida percorrida por uma dinâmica de muita mobilidade náo deixa de ser percebido por Romano. O jurista reage contra o autoritarismo estatal, criticando o normativismo que supóe um sistema de validade transcendente, independente de um trajeto histórico e atemporal (BAQUER, 1963, p. 23).

As teses de Romano - a primazia do direito ordenamental sobre o direito potestativo e o direito enquanto instituição - contribuem para a solução de duas contradiçóes inerentes ao positivismo jurídico. Com a identificação do direito à sociedade, resolve-se o problema da disjunção entre ser e deverser. O direito passa a se configurar como expressão das práticas sociais, do mundo dos fatos - ser -, não apenas uma prescrição abstrata e, em geral, desvinculada da realidade - dever-ser (ZICCARDI, [198?], p. 310) ${ }^{28}$. E, com a identificação do ordenamento jurídico à instituição, soluciona-se a questão do fundamento da norma fundamental. $\mathrm{Na}$ visão positivista, essa seria a fonte última da validade do sistema jurídico, mas onde se apóia a validade da norma fundamental? Para Romano, não há uma norma preexistente ao surgimento do ordenamento, uma vez que esse existe no momento em que existe a instituição.

\footnotetext{
27 "O direito é mais aplicação do que norma. Seria um desastre se um comando fosse imobilizado, ainda mais se 0 comando encontra a sua própria imobilização em um texto; seria um desastre se a regra jurídica se tornasse e permanecesse somente um pedaço de papel. O provável risco é que essa se separe da vida. O direito é, em primeiro lugar, ordenamento; com isso vem salientado, além da mudança terminológica, que a sua autoridade está nos conteúdos em que se entrelaça e que propõe, está no fato de ser leitura objetiva da realidade, tentativa de racionalização do real. É uma autoridade que se move debaixo para cima, que torna espontâneo o aceite social e a observância - que é o grande mistério do direito - por isso mesmo perde a repugnância da coerção. Com o direito-ordenamento o homem do povo também pode se reconciliar" (GROSSI, 2004, p. 91).

${ }^{28} \mathrm{O}$ autor afirma que, assim, Romano evita o erro capital do positivismo: 0 de colocar à base do direito a vontade estatal.
} 
O aspecto fundamental e primário do direito é determinado pela instituição em que esse se concretiza e não pelas normas ou, em geral, pelos preceitos com que este se realiza. Estes constituem, ao contrário, um aspecto derivado e secundário. Se temos por referência o momento em que surgem determinadas instituiçóes e, conseqüentemente, começa a ter vida o seu ordenamento, vemos de imediato que este momento não é determinado por uma norma preexistente, e que, deste modo, é impossível considerar que o direito não seja uma instituição [...]. Isso é evidente, por exemplo, para o Estado, mas náo somente para o Estado. [...] A sua origem não é um procedimento regulado por normas jurídicas; é, como repetidamente evidenciamos, um fato. Ora, basta que este fato seja consumado para que tenhamos direito, basta que tenhamos um Estado efetivo, vivo e vital; a norma, ao contrário, pode ser instituída a seguir. A primeira posição do direito não é, deste modo, determinada pela última, que é uma manifestação mais tardia e subsidiária daquela. De resto, não pode existir direito antes e fora da instituição justamente porque falta a organização que torna jurídica a norma. $\mathrm{O}$ direito não pode ser somente a norma posta pela organização social, como freqüentemente se afirma, mas é a organização social que, entre as suas outras manifestaçóes, pôe também a norma. Se é verdade que o caráter jurídico da norma é fornecido pelo poder social que a determina, ou, ao menos, a sanciona, disto advém que este caráter deve ser encontrado já na instituição, que não poderia atribuí-lo à norma se essa mesma já não o possuísse. $\mathrm{A}$ verdade é que o direito é, antes de mais nada, posição, organização de uma entidade social. Se este postulado não é aceito, se vai ao encontro do inconveniente de ter de explicar de modo metajurídico o fundamento e a obrigatoriedade do direito (ROMANO, 2006, p. 43-44).

A visão ordenamental de Romano, ao retirar o eixo do direito da autoridade e levá-lo para a sociedade, revela-se também pluralista. A produção jurídica não se limita mais ao aparelho estatal, uma vez que o meio social abriga uma infinidade de instituiçóes, ou seja, de ordens jurídicas autônomas, independentes, coordenadas ou subordinadas ao Estado (ROMANO, 2006, p. 82). Não se trata de uma mensagem anárquica, na medida em que Romano, assim como Hauriou, reconhece o ordenamento estatal como conceito-chave 
para a compreensão dos demais. É, simplesmente, uma mensagem pluralista (GROSSI, 2007, p. 21) ${ }^{29}$. Ao mesmo tempo em que o Estado é compacto e, por isso mesmo, "é intolerante à diversidade, a sociedade é um grande ventre materno capaz de gerar, hospedar e nutrir manifestaçóes jurídicas caracterizadas pela mais clara diversidade substancial” (ROMANO, 2006, p. 22).

\section{Santi Romano: a sociedade internacional}

Romano não descuida da importância da organização estatal, embora reconheça sua insuficiência enquanto produto do individualismo. Segundo ele, o edifício político-jurídico construído pelo Iluminismo e pela Revolução Francesa, quando quis por perante o Estado somente o indivíduo, levou consigo seu pecado original: o de ser excessivamente simples (ROMANO, $1950 \mathrm{a}, \mathrm{p} .317)^{30}$. A complexa composição da sociedade não pode ser reduzida a uma dialética elementar entre pessoas: o Estado-pessoa e a pessoa individual e física. Romano reconhece, já no início do século XX, uma multiplicidade de associaçóes que nascem ao redor do Estado, concluindo que o direito público não domina, mas é dominado por uma dinâmica social que ultrapassa a esfera do indivíduo (ROMANO, 1950a, p. 316-318). Entretanto, justamente por questionar fórmulas modernas tidas como dogmas, o jurista reconhece os riscos imperialistas de uma suposta federação universal. Ele não crê em um mundo reduzido a três ou quatro colossais sistemas políticos, mas sim em leis gerais baseadas em fatos e respeitadas por todas as naçóes (ROMANO, 1950b, p. 355).

Como, então, explica-se o monismo de sua teoria, na contraposição entre direito interno e direito internacional? Ora, não é o Estado que cria o direito internacional, mas a instituição comunidade internacional, ou seja, o próprio direito internacional, que cria os $\operatorname{Estados}^{31}$. Na visão romaniana,

\footnotetext{
${ }^{29}$ A tese de Romano de uma pluralidade ilimitada dos ordenamentos jurídicos constitui o reconhecimento da natureza pluralística da sociedade e da natureza conflituosa das relações sociais. Eis mais um efeito da teoria institucional: as forças sociais tornam-se relevantes quando assumem características estruturais elevadas, configurando-se como sociedade e, portanto, como ordenamento jurídico (ZICCARDI, [198?], p. 320-321).

${ }^{30}$ Veja também Grossi (2000, p. 109-117).

31 "Como o direito estatal se põe juntamente com a existência do Estado - sendo a existência deste último e o respectivo ordenamento jurídico considerados como um único fenômeno - também o direito internacional se põe juntamente com
} 
seria metafísico imaginar o homem isolado, vivendo em estado de natureza antes de se estabelecer o direito que regulará sua conduta social. Da mesma forma, conceber os Estados isolados de seus pares, fora da comunidade internacional, é uma abstração quase mítica (ROMANO, 2006, p. 48). A atual independência recíproca dos Estados não pode ser entendida como uma condição natural, preexistente ao direito internacional, já que é posta por esse. Ademais, essa independência é fato relativamente recente, já que, antes da Idade Moderna, o direito internacional fundava-se justamente na submissão dos Estados ao poder temporal do Império Romano ou ao poder espiritual da Igreja (ROMANO, 2006, p. 49).

Se a autonomia dos Estados não conforma, então, "uma condição natural, originária, independente do direito internacional, mas é, de fato, contingente" (ROMANO, 2006, p. 49), resultado de particularidades históricas, a constituição do ordenamento internacional independe da vontade estatal. Romano nega, assim, as concepçóes nacionalistas, soberanistas e voluntaristas do direito internacional, compreendendo-o como um direito objetivo fundado na existência da comunidade internacional ${ }^{32}$. Essa seria uma instituição com poder normativo intrínseco, mesmo sem contar com uma completa organização política. Seu poder é diferente do poder dos Estados, na medida em que a coexistência deles origina um novo corpo institucional, situado para além de uma mera justaposição dos entes estatais. Como essa situação necessariamente enseja normas fundamentais de convivência, considera-se a sociedade internacional como um processo histórico complexo que se impôs à vontade dos Estados, não o contrário ${ }^{33}$.

Nessa lógica, o problema fundamental do direito internacional reduz-se ao problema da existência de uma sociedade internacional organizada, de uma instituição internacional - a instituição das instituiçóes (TRUYOL Y

a existência da comunidade dos Estados, que postula necessariamente um ordenamento jurídico que a constitua e a regule" (ROMANO, 2006, p. 49).

${ }^{32} \mathrm{~A}$ aplicação de Romano da teoria das instituições ao estudo do direito internacional, tendente a identificar ordenamento internacional e sociedade internacional, elimina a exigência de uma norma fundamental e o problema relativo ao fundamento do direito internacional, posto pelas doutrinas ancoradas na vontade estatal (ZICCARDI, 2000, p. 71).

${ }^{33}$ Ainda comparando o ordenamento internacional ao ordenamento interno, Romano afirma que ambos afirmam-se, em um primeiro momento, como instituição. A instituição explica o momento originário, o fundamento do direito. As normas são emanadas dos órgãos estatais ou dos Estados apenas posteriormente, depois que os ordenamentos estão constituídos (ROMANO, 2006, p. 49). 
SERRA, 1951, p. 80) $)^{34}$. A indagação sobre a efetividade desse direito inserese nesse problema fundamental, ao qual Romano apresenta as soluçóes da teoria institucionalista. Para ele, a questão essencial refere-se à constituição do ordenamento jurídico, tanto no plano interno quanto no âmbito internacional (ZICCARDI, 2000, p. 72). A eficácia dessa ordem depende dos princípios e mecanismos definidos no processo de sua formação, não das sanções estipuladas. As respostas devem ser buscadas nos elementos essenciais, não secundários de um objeto, e a sanção não configuraria mais do que uma característica incidental do direito. A observância do direito internacional pelos Estados deve derivar, portanto, do reconhecimento da existência de uma vontade única, superior às vontades estatais, relativa ao poder impessoal e não subjetivo da comunidade (ROMANO, 2006, p. 46). Desse ponto resultaria o caráter obrigatório da ordem internacional, que existe mesmo que seus sujeitos se encontrem em uma relação de coordenação - não de subordinação - para com ela e entre eles próprios. Sobre as sanções, Romano entende que o essencial em um ordenamento é a adequação das garantias contidas nele à sua efetividade e não, ao contrário, a predisposição de sançóes seguramente atuantes em relaçóes às violaçóes do direito (ZICCARDI, [198?], p. 314).

A teoria institucionalista de Romano não afirma somente a existência do direito internacional, mas também sua autonomia. Defende sua importância enquanto direito de toda a comunidade internacional, contendo regras que podem se referir a todos os seus membros - direito comum: princípios da natureza da comunidade internacional e de seus costumes - e que fundamentam os tratados bilaterais - direito particular. Esse direito comum internacional, embora por vezes não escrito, é direito positivo, não apenas manifestação da vontade estatal. A moldura do direito positivo ultrapassa essa vontade e a limita ${ }^{35}$. Com seu monismo interinstitucional, Romano abre novos caminhos para afrontar antigos problemas do direito internacional, ainda relacionados à insuficiência da concepção normativista.

34 "O problema então, para nós, está todo no questionamento: a ordem jurídica internacional é uma instituição? Não temos dúvida quanto ao lugar onde esta figura deve ser procurada: deve-se indagar se a comunidade dos Estados apresenta as características constitucionais que, segundo a opinião por nós formulada, são também as características essenciais de todo sistema jurídico" (ROMANO, 2006, p. 45).

35 Truyol y Serra $(1951$, p. 80). 


\section{O olhar antiformalista de Riccardo Monaco sobre a ordem jurídica comunitária}

A teoria de Santi Romano, embasada, em certa medida, no institucionalismo de Maurice Hauriou, influenciou significativamente a cultura jurídica italiana do século XX (TRUYOL Y SERRA, 1951, p. 80). Riccardo Monaco está entre os juristas nos quais a linha de pensamento romaniana pode ser claramente observada ${ }^{36}$. Seus trabalhos atualizam a teoria institucionalista e a aplicam às situaçóes que não puderam ser diretamente analisadas por Romano. Uma vez que Monaco dedica uma de suas principais obras ao direito comunitário europeu emergente, é interessante verificar em que medida o pluralismo internacionalista romaniano faz-se presente em tal exame. O objetivo da seção é discutir as bases antiformalistas da análise jurídica de Riccardo Monaco acerca da Comunidade Européia (CE), buscando compreender as razóes pelas quais o direito comunitário adota postulados antiformalistas enquanto o direito internacional público parece continuar resistente a eles.

Segundo Paolo Grossi, Santi Romano é um dos poucos juristas que redescobrem a complexidade do universo jurídico após a subjetivação do direito na modernidade (GROSSI, 2007, p. 7). Na passagem da Idade Média à Idade Moderna, o direito se transforma de ordenamento em poder e passa a ter na autoridade estatal sua referência primária. $\mathrm{O}$ sistema jurídico moderno exprime o Estado e não a sociedade, contradição que resulta na crise do sistema na contemporaneidade. $\mathrm{O}$ internacionalista italiano

\footnotetext{
${ }^{36}$ Riccardo Monaco (1909-2000), jurista genovês, doutorou-se em Direito em Turim em 1930. Foi juiz em Turim e professor das Universidades de Cagliari, Modena, Turim e Roma, além de ter sido assessor do Ministério das Relações Exteriores da Itália e juiz do Tribunal de Justiça das Comunidades Européias entre 1964 e 1976. Entre suas principais obras, estão L'ordinamento internazionale in rapporto all'ordinamento statuale (1932), Manuale di diritto internazionale pubblico e privato (1949), Lo stato e il suo ordinamento giuridico (1952), Diritto delle Comunità Europee e Direitto Interno (1967) e Manuale di diritto internazionale pubblico (1971).
} 
olha com atenção, curiosidade, mas também com preocupação ao grande movimento entre os anos dos séculos XIX e XX, contempla a erosão das muralhas do castelo legal após o assalto de uma quantidade imensa de novidades e mutaçóes que sacodem o panorama, contempla a incapacidade do Estado e da lei, sempre mais distante e separada da história vencedora, e tenta organizar a complexidade já descoberta (GROSSI, 2007, p. 16) ${ }^{37}$.

Romano busca determinar a realidade jurídica de modo objetivo e concreto, sem o auxílio da erudição ou de métodos, teorias e juízos préconcebidos (BAQUER, 1963, p. 25) ${ }^{38}$. O jurista procura superar, assim, a fixação dessa realidade exclusivamente sobre uma base normativa. A crítica ao positivismo jurídico é também uma forma de reação contra o totalitarismo estatal: o direito náo corresponde unicamente a um conjunto de normas com raízes na vontade do Estado, mas refere-se também ao que nelas está contido (BAQUER, 1963, p. 37). O direito é, portanto, uma organização em que as normas são objeto e instrumento. A comunidade internacional é também uma instituição nesse sentido, cujo poder normativo não advém do Estado, mas lhe é próprio desde sua origem. O direito internacional, como ordenamento, é sempre provido de instituiçóes, sendo ao mesmo tempo uma (ZICCARDI, [198?], p. 316). Com o surgimento, na Europa, de uma ordem jurídica sui generis - o direito comunitário -, que não se confunde nem com os direitos internos dos Estados-membros nem com o direito internacional, cabe perguntar: essa explicação do antiformalismo institucionalista para as relaçóes entre o direito interno e o direito internacional público repete-se no caso das relaçóes entre o direito interno e o direito comunitário?

Explicitando sua base romaniana, Monaco afirma que a comunidade internacional compreende uma pluralidade de ordenamentos, onde se inserem o Estado e outros entes - dentre os quais destacam-se as

\footnotetext{
37 "Aos nossos olhos, Romano, mais do que qualquer outro jurista italiano, é aquele que se torna intérprete da acima citada grande crise entre os dois séculos [XIX e XX], com a tentativa - conseguida - de dar a esta em vulto técnico, de tentar resolvê-la utilizando as idéias, o léxico, a armadura técnica da ciência jurídica. O ordenamento jurídico, no ano de 1918, ano final da grande tragédia bélica mundial, constitui uma reposta serena e meditada aos graves problemas que os críticos tinham impiedosamente levantado" (GROSSI, 2007, p. 15).

${ }^{38}$ Para Paolo Grossi, Romano nega-se - por trás de um imperativo que é ao mesmo tempo ético, cultural, técnico - a "parar perante princípios e fórmulas que se apresentam com a consistência de dogmas" (2007, p. 18).
} 
organizaçóes internacionais (MONACO, 1967, p. 5). Logo, a relação entre os ordenamentos comunitário e estatal é apenas uma das relaçóes possíveis no âmbito internacional.

A fim de analisar em profundidade essa relação, Monaco aponta a necessidade de, primeiramente, especificar as características do direito comunitário. Um primeiro atributo refere-se ao surgimento desse ordenamento: a ordem européia não nasce de qualquer tratado internacional, mas de um tratado que estabelece um novo ente. Esse ato não resulta apenas da vontade comum dos Estados durante a negociação, mas refere-se a um período temporal anterior, no qual reside a decisão política dos governos acerca da criação da entidade. "Isso vincula o nascimento do ente a um fato pré-jurídico e assim confere ao ente, uma vez criado, uma ligação com a realidade política" (MONACO, 1967, p. 8) ${ }^{39}$. Com essa idéia, Monaco ressalta os estreitos liames entre o direito e a realidade política que lhe é correspondente. Tal noção oferece concretude e dialeticidade ao processo de criação do direito, afastando o caráter metafísico e abstrato do "legislador" onipotente e das normas jurídicas positivadas.

O jurista já reconhecia, à época, o caráter constitucional do ato constitutivo da Comunidade Européia, colocando-o no ápice do ordenamento e comparando os Estados que o conformaram a uma espécie de poder constituinte originário. Esse ato, contudo, não possui apenas porte constitucional, mas também finalidade normativa, ao regular, por exemplo, a estrutura e as competências da entidade, que não são deixados à discricionariedade dos Estados. A natureza constitucional confere um caráter de permanência ao tratado, que não pode ser derrogado por outras normas firmadas entre os membros, mesmo que especiais. Outra característica marcante é a duração ilimitada no tempo do tratado constitutivo, que, diferentemente de grande parte dos acordos internacionais convencionais, não tem uma duração pré-estipulada nem pode ser denunciado pelas partes contratantes. Ora, o ato constitucional não dá origem a um conjunto de normas, mas a um ordenamento jurídico, que não poderia se completar no tempo e expandir-se gradualmente se sua base pudesse ser facilmente

\footnotetext{
${ }^{39}$ Livre tradução do original: "Il che collega la nascita dell'ente a un fato pregiuridico e quindi conferisce all'ente, una volta che sia nato, un collegamento con la realtà poitica”.
} 
colocada em discussão (MONACO, 1967, p. 20). Tais elementos, segundo Monaco, são essenciais para diferenciar um tratado constitutivo de uma organização internacional de um simples tratado normativo (MONACO, 1967, p. 14). O primeiro, por ter um impacto maior do ponto de vista jurídico, não poderia ser abandonado às contingências que influenciam o segundo. A partir desse raciocínio, poderia-se questionar se o Tratado de Assunção, constitutivo do Mercosul, contraditoriamente não se assemelha mais a um singelo acordo normativo: pode ser denunciado pelos membros a qualquer tempo, não conhece necessariamente força hierárquica sobre normas posteriores ou especiais elaboradas pelos Estados e tem seu alcance freqüentemente relativizado por declarações e atos de autoridades políticas nacionais.

Mesmo compartilhando a noção-base de tratado constitutivo, o ordenamento comunitário diferencia-se consideravelmente dos ordenamentos das demais organizaçóes internacionais (MONACO, 1967 , p. 62). Estruturalmente, a CE possui um elemento representativo normalmente ausente dos entes internacionais: um órgão parlamentar. Em seus primórdios, a assembléia já denotava o caráter político da Comunidade e promovia mediaçóes entre as várias correntes ideológicas existentes nos Estados-membros. No plano decisório, adota-se a regra da maioria. As negociações derivadas da constante observância desse princípio possibilitam que se passe da colaboração associativa entre Estados à colaboração estrutural. Gradualmente, os interesses comunitários acabam por prevalecer sobre os interesses dos membros, o que favorece a integração dos ordenamentos nacionais ao ordenamento da Comunidade. Com relação aos efeitos jurídicos, as normas européias têm a capacidade de obrigar diretamente os sujeitos dos ordenamentos estatais - princípio do efeito imediato -, não apenas o próprio Estado, como ocorre na maioria das organizaçôes internacionais.

Segundo Monaco, a Comunidade Européia possui um ordenamento jurídico próprio pois atende a três requisitos: a) é constituída por uma pluralidade de sujeitos jurídicos, cuja vinculação conforma um grupo social; b) verifica-se a presença de uma regulação autônoma, isto é, de um conjunto de normas que lhe são particulares uma vez que derivam de fontes próprias; e c) possui uma estrutura orgânico-institucional que lhe confere instrumentos 
para a ação e, assim, para a consecução dos objetivos indicados no tratado constitutivo (MONACO, 1967, p. 21).

Embora Riccardo Monaco reconheça que a ordem comunitária é um sistema jurídico complexo, no qual convergem múltiplos elementos jurídicos, o autor afasta a hipótese de que ele seria composto de vários ordenamentos jurídicos (MONACO, 1967, p. 25). O jurista refuta, portanto, a idéia romaniana segundo a qual, com a criação da Comunidade, teria surgido uma instituição que compreende outras instituições. Para justificar sua posição, ele argumenta que são inseparáveis a união internacional formada pelos Estados-membros e o sistema jurídico comunitário. Não haveria relação de subordinação entre ambas instituições, pelo simples fato de que elas representam uma só instituição. Monaco não vê na estrutura da Comunidade Européia uma instituição maior integrada por instituiçôes menores, condição necessária para que se aplique o raciocínio de Romano. Segundo ele, existe na $\mathrm{CE}$ apenas uma instituição, complexa mas unitária, que compreende tanto a união entre os Estados quanto o organismo comunitário criado por ela. Não haveria distinção entre instituição originária - união de Estados - e derivada - Comunidade -, tampouco entre os sujeitos aos quais se destina o direito originário e o direito derivado.

Essa interpretação de Monaco visa observar a finalidade essencial dos tratados constitutivos, que é a de "dar vida a um sistema de integração jurídica, ao invés de um simples sistema de cooperação entre Estadosmembros" (MONACO, 1967, p. 26) ${ }^{40}$. Em 1967, ano das mencionadas análises de Monaco, a CE apenas dava seus primeiros passos. Contava somente com os seis Estados-membros fundadores, a assembléia parlamentar não era eleita diretamente, a política agrícola comum acabava de ser lançada e os princípios da aplicação imediata, do efeito direto e da primazia do direito comunitário haviam sido recentemente delineados pelo Tribunal de Justiça. Para a consolidação da integração regional, era muito importante relembrar as características de unidade, autonomia e eficácia da ordem comunitária definidas nos tratados. Assim, não se pode dizer que Monaco afasta os pressupostos antiformalistas ao negar a pluralidade de ordenamentos

\footnotetext{
${ }^{40}$ Livre tradução do original: "[...] dar vita ad un sistema d'integrazione giuridica, anzichè ad un simplice sistema di cooperazione fra gli Stati membri”.
} 
jurídicos no seio da Comunidade. Se contextualizado, seu entendimento coaduna-se com a necessidade de afirmação do direito comunitário à época. Ademais, a discussão acerca do papel das regióes, dos sindicatos e de outros atores subnacionais ainda era incipiente. Com o nascimento do Comitê das Regióes (apenas em 1994) e de outros órgáos comunitários destinados a regular e a potencializar a atuação dos atores subestatais na cena européia, a Comunidade acaba por reconhecer a existência de novos sujeitos e ordenamentos no âmbito regional.

Para Monaco, portanto, o ordenamento comunitário é autônomo e independente, pois difere do ordenamento internacional e das ordens internas dos membros ${ }^{41}$. O caráter unitário é assegurado sobretudo por meio da uniformidade de interpretação das normas européias e pela paridade de eficácia das normas nos ordenamentos internos dos Estados-membros. Por fim, o direito comunitário é dotado de eficácia, pois suas normas dispóem de meios e instrumentos para se realizar, além de serem assistidas por uma particular e direta garantia jurisdicional que recai sobre Estados e pessoas físicas e jurídicas.

No tocante às relações entre o ordenamento comunitário e os ordenamentos nacionais, elas são de integração jurídica, embora ambos ordenamentos não se confundam. Ademais, não há hierarquia entre eles: se é possível verificar alguma relação de sobreposição, ele ocorre entre normas, não entre ordenamentos. Isso significa que o princípio da primazia do direito comunitário, basilar para a integração, refere-se apenas a normas comunitárias em assuntos de competência da Comunidade, não ao ordenamento em abstrato, o que poderia ferir o princípio da subsidiariedade. A noção de integração jurídica criada com a CE é diferente da simples cooperação entre Estados, fenômeno ocasional que não altera a estrutura normativa de seus ordenamentos, e também da união entre Estados, que se move apenas no plano horizontal, embora comporte trocas normativas. Trata-se de um conceito que náo se enquadra em modelos preexistentes e que complementa necessariamente o objetivo de integração econômica (MONACO, 1967, p.

\footnotetext{
41 "Pela sua novidade, pela originalidade de sua estrutura, o ordenamento comunitário não pode ser enquadrado em nenhum tipo de Estado ou de união de Estados" (MONACO, 1967, p. 24). Livre tradução do original: "Per la sua novità, per l'originalità della sua struttura, l'ordinamento comunitário non è classificabile in alcun tipo di Stato o d'unioni di Stati”.
} 
110).

A análise da obra de Riccardo Monaco enseja duas conclusóes principais. Em primeiro lugar, seu exame acerca do ordenamento jurídico comunitário traz tópicos hoje pacíficos para os estudiosos do tema, mas que na época não o eram. O direito comunitário representa uma construção antiga que mistura basicamente a normativa européia, as decisóes do Tribunal e a interpretação doutrinária. Quando escreveu, Monaco desafiava muitos postulados jurídicos arraigados nas culturas jurídicas nacionais que hoje já se encontram bastante flexibilizados em nome de um direito comum. Em segundo lugar, percebe-se a estrutura do antiformalismo institucionalista em seu modo de pensar a integração regional. Ou seja, as reflexóes de Santi Romano sobre a comunidade internacional encontram-se na origem das análises da escola italiana acerca do ordenamento comunitário. Sem repetir os postulados romanianos, mas complementando-os e adaptando-os à nova realidade, Monaco oferece uma decisiva contribuição antiformalista ao desenvolvimento do direito da Comunidade Européia.

Segundo o jurista, o ordenamento jurídico comunitário torna-se uma realidade no momento em que a cooperação internacional abandona o costumeiro modo de operar, mediante relaçóes horizontais, e se volta a uma estrutura vertical (MONACO, 1967, p. 24). Os processos de integração regional poderiam ser compreendidos, nessa ótica, como uma etapa de transição a um direito internacional dotado de mais eficácia. Nesse ponto, é preciso esclarecer que essa eficácia não se refere à perda das conquistas históricas do Estado de direito. Não se trata aqui da relativização de direitos ou da edificação de um "superEstado" na esteira de uma espécie de imperialismo mundial, para o qual já alertava Romano. Trata-se, isso sim, do alargamento de direitos para além fronteiras, que corresponda a uma cooperação pela diminuição dos conflitos armados e na solução de problemas sociais e econômicos cuja origem não se restringe aos limites geográficos do Estado-nação. É precisamente por isso que se fala em direito internacional e da integração: trata-se de regular democraticamente os âmbitos regional ou internacional, e não deixá-los à deriva da atuação de poucos agentes transnacionais.

Por outro lado, é legítimo questionar-se acerca dos motivos pelos quais a 
Europa logrou a construção de um ordenamento eficaz, enquanto o direito internacional público segue com seu tradicional déficit de efetividade. Não é desprezível o fato de que a maioria dos ordenamentos internos, no início da CE, eram orientados no sentido de reconhecer a proeminência do direito comunitário. Essa situação conformou um importante critério interpretativo na solução de casos práticos posteriormente condensado em princípio jurídico. Nesse sentido, a adoção de uma ótica antiformalista, sobretudo quanto à relativizaçáo da soberania estatal, à supremacia do direito sobre o Estado e ao reconhecimento de atores não estatais na cena internacional, viria ao encontro de uma possível maior eficácia das determinaçóes do direito internacional. 


\section{Referências Bibliográficas}

BAQUER, Sebastián Martín-Retortillo. Estudio prelimiar: la doctrina del ordenamiento jurídico de Santi Romano y algunas de sus aplicaciones en el campo del derecho administrativo. In: ROMANO, Santi. El ordenamiento jurídico. Madrid, Instituto de Estudios Politicos, 1963, p. 9-77.

BILLIER, Jean-Cassien; MARYIOLI, Aglaé. História da filosofia do direito. Barueri: Manole, 2005.

BOBBIO, Norberto. O positivismo jurídico: liçôes de filosofia do direito. São Paulo: Ícone, 1995.

DAL RI JR, Arno. O antiformalismo de Santi Romano e a doutrina italiana de direito internacional. 2006. Mimeografado.

GRAU, Eros. O direito posto e o direito pressuposto. São Paulo: Malheiros, 1996.

GROSSI, Paolo. Mitologias jurídicas da modernidade. Florianópolis: Fundação Boiteux, 2004.

. O direito entre poder e ordenamento. Tradução de Ângelo Garzarella e Arno Dal Ri Jr. 2007. Mimeografado.

. Primeira lição sobre direito. Rio de Janeiro: Forense, 2006.

. Scienza giuridica italiana: un profilo storico (1860-1950). Milano:

Giuffrè, 2000.

HAURIOU, Maurice. Aux sources du droit: le pouvoir, l'ordre et la liberté. Paris: Bloud, 1933.

. Précis de droit constitutionnel. 2. ed. Paris: Librairie du Recueil Sirey, 1929.

HESPANHA, António Manuel. Cultura jurídica européia: síntese de um milênio. Florianópolis: Fundação Boiteux, 2005.

KELSEN, Hans. Teoria pura do direito. 4. ed. Coimbra: Armênio Amado Editor, 1976. 
KELSEN, Hans; CAMPAGNOLO, Umberto. Direito internacional e estado soberano. São Paulo: Martins Fontes, 2002.

LYRA FILHO, Roberto. O que é direito. 17. ed. São Paulo: Brasiliense, 2003.

MONACO, Riccardo. Diritto delle Comunità Europee e direitto interno. Milano: Giuffrè, 1967.

PALIANI, Stefania. O institucionalismo puro de Santi Romano e de Maurice Hauriou. Tradução de Arno Dal Ri Jr. 2007. Mimeografado.

ROMANO, Santi. Lo stato moderno e la sua crisi. In: ROMANO, Santi. Scritti minori: diritto constituzionale. Milano: Giuffrè, 1950a. p. 311-325. (Volume1).

- O ordenamento jurídico. Tradução de Arno Dal Ri Jr. 2006. Mimeografado.

- Oltre lo stato. In: ROMANO, Santi. Scritti minori: diritto constituzionale. Milano: Giuffrè, 1950b. p. 345-356. (Volume 1).

ROUSSEAU, Jean-Jacques. Contrato social. São Paulo: Martin Claret, 2001.

TRIEPEL, Karl Heinrich. As relaçóes entre o direito interno e o direito internacional. Revista da Faculdade de Direito da Universidade Federal de Minas Gerais, Belo Horizonte, ano XVII, n. 6, p. 8-64, out. 1966.

TRUYOL Y SERRA, Antonio. Doctrines contemporaines du droit des gens. Paris: Pedone, 1951.

WOLKMER, Antonio Carlos. Pluralismo jurídico: fundamentos de uma nova cultura no Direito. 3. ed. São Paulo: Alfa Omega, 2001.

- Sintese de uma história das idéias jurídicas: da antigüidade clássica à modernidade. Florianópolis: Fundação Boiteux, 2006.

ZICCARDI, Piero. La costituzione dell'ordinamento internazionale. Milano: Giuffrè, 2000.

. Le dottrine Giuridiche di Oggi e L'Insegnamento di Santi Romano: il diritto internazionale. Vita Giuridica Internazionale, Milano, p. 307-322, [198?]. 